\title{
Relationship Of Health Care Quality With Interest In Patient Re-Visits At Cangkringan Sleman Health Center
}

\author{
Kunik Afifah \\ Nursing Undergraduate Study Program, STIKES General Achmad Yani Yogyakarta
}

\begin{tabular}{|c|c|}
\hline ARTICLE INFO & ABSTRACT \\
\hline $\begin{array}{l}\text { Keywords: } \\
\text { Quality of Health Services, } \\
\text { Interest in Re-Visits, Health } \\
\text { Centers }\end{array}$ & $\begin{array}{l}\text { Good service quality will provide satisfaction to customers } \\
\text { which ultimately customers will reuse and recommend } \\
\text { these health services to people around them. So that it } \\
\text { affects the repurchase decision making which will affect } \\
\text { consumers about the services provided. Good and quality } \\
\text { services will increase the number of visits which in turn } \\
\text { will increase the income of the Puskesmas. This study aims } \\
\text { to determine the relationship between the quality of health } \\
\text { services and the interest in repeat visits of patients at the } \\
\text { Cangkringan Sleman Public Health Center } \\
\text { This study uses a quantitative design with a cross sectional } \\
\text { research design by collecting data using a questionnaire. } \\
\text { The number of samples used in this study were } 75 \\
\text { respondents with the sampling technique used was } \\
\text { accidental sampling. Statistical analysis used the } \\
\text { Contingency Coefficient test with a } 95 \% \text { confidence level } \\
\text { ( } \alpha=0.05) \text {. The results of this study indicate that there is a } \\
\text { relationship between the quality of health services and the } \\
\text { interest in repeat visits of patients at the Cangkringan } \\
\text { Sleman Health Center with a value of } p=0.031, \mathrm{r}=0.241 \text {. } \\
\text { There is a significant relationship between the quality of } \\
\text { health services and the interest in repeat visits, namely the } \\
\text { more patients who visit, the better the service quality of } \\
\text { Cangkringan Sleman Health Center. }\end{array}$ \\
\hline E-mail: kunikafif14@gmail.com & $\begin{array}{r}\text { Copyright (C) } 2021 \text { Eduhealth Journal.All rights reserved. } \\
\text { is Licensed under a Creative Commons Attribution- } \\
\text { NonCommercial 4.0 International License (CC BY-NC 4.0) }\end{array}$ \\
\hline
\end{tabular}

\section{INTRODUCTION}

Law Number 36 of 2009 concerning Health, explains that health is the condition of every person who shows good physical, mental, spiritual and social health that allows everyone to live socially and economically productive. Article $28 \mathrm{H}$ of the 1945 Constitution states that everyone has the right to get health services, so every individual, family and community has the right to obtain health protection. The development of health efforts in the National Health System (SKN) in 2009 is a form and method of implementing health development that combines various efforts of the Indonesian people in one step to ensure the achievement of development goals in the context of realizing people's welfare as referred to in the 1945 Constitution (Ministry of Health, 2009). ). Based on Health Law Number 23 of 2009 emphasizes the importance of efforts to improve the quality of health services, especially at the Puskesmas level. Based on the Decree of the Minister of Health (Kemenkes) No. 128 of 2004, the Community Health Center or Puskesmas as the Service Technical Implementation Unit (UPTD) is an organizational unit that is given independent authority by the District Health Office to carry out operational technical tasks for health development in the sub-district area. Within the Puskesmas, there are six main health efforts that must be carried out by every Puskesmas in the territory of Indonesia Community Health Centers or Puskesmas as Service Technical Implementing Units (UPTD) are organizational units that are given independent authority by the District Health 
Office to carry out operational technical tasks for health development in the sub-district area. Inside the Puskesmas, there are six main health efforts that must be carried out by every Puskesmas in the territory of Indonesia Community Health Centers or Puskesmas as Service Technical Implementing Units (UPTD) are organizational units that are given independent authority by the District Health Office to carry out operational technical tasks for health development in the sub-district area. Within the Puskesmas, there are six main health efforts that must be carried out by every Puskesmas in the territory of Indonesia[1]. Efforts to maintain and improve health are realized in a service container or what is often referred to as health facilities or services. Health services are places or facilities that are often used by the community to carry out health efforts[2]. Muninjaya[3]stated that Community Health Centers (Puskesmas) in Indonesia began to be developed since the first Long Term Development (PJP) was planned in 1971. Puskesmas is a health service unit which is the spearhead in the field of basic health. The government developed Puskesmas with the aim of bringing health services closer to the community, most of whom still live in rural areas. Puskesmas are expected to provide quality, satisfactory health services, in accordance with professional standards and ethics[4]. The health program organized by the puskesmas is a public health essential program that must be implemented by the government to protect its population. The programs are the basic health program (The Basic Six) and the development health program. Meanwhile, the development health program is another program that is in accordance with the conditions, problems and capabilities of the local health center[5].

Good service quality will provide satisfaction to customers which ultimately customers will reuse and recommend these health services to people around them[6]. So that it influences repurchase decisions which will later affect consumers about the services provided. Good and quality services will increase the number of visits which in turn will increase the total income of the Puskesmas[7]. Mabow[8] explained that quality service at the Puskesmas means providing services to patients based on quality standards to meet the needs and desires of the community, so that they can obtain satisfaction with increasing patient trust and loyalty to the Puskesmas. To achieve quality and affordable health services, it is necessary to carry out service efforts in accordance with professional standards, namely tangible (physical evidence), reliability (reliability), responsiveness (responsiveness), assurance (guarantee) and empathy (empathy).[9].

Because the interest in consumer behavior in buying or using services from service providers is strongly influenced by the experience of satisfaction with the services provided previously. After receiving health services, patients will compare the services received with the expected services[10]. Therefore, the decrease in the number of long visits indicates that the interest in patient visits to return to puskesmas services has also decreased. The services of medical personnel, paramedics, facilities and infrastructure can also improve the quality of service if users can feel and are interested in reusing the service[11]. Based on data from the Sleman Health Service in 2015, Sleman Regency is one of the regencies in the Special Region of Yogyakarta which has an area of $574.82 \mathrm{Ha}$ or $\pm 18 \%$ of the total area of the Special Region of Yogyakarta. Sleman Regency itself consists of 17 sub-districts with 86 villages and 1,212 hamlets. In each sub-district there are one to three main health centers, depending on the area of the subdistrict and population density, so that in Sleman Regency there are 25 main health centers. Each puskesmas serves a community of approximately 30,000-50,000 people. Of the 25 existing health centers, five of them are health centers that have inpatient services. In 2014, the Cangkringan Health Center was the health center with the least number of patient visits among the puskesmas in the Sleman area, which was 19,520 people. Meanwhile, in 2015, Cangkringan Health Center there was an increase in the number of patients who visited, which was around 25,052 people. And in 2016 the number of visits in one year decreased by 20,438 people. Based on the results of preliminary studies that have been carried out, Cangkringan Sleman Health Center has health services including general poly, dental and oral poly, family planning and KIA poly, laboratory, psychological consultation and nutrition consultation. Based on interviews from 15 respondents who received treatment at the Cangkringan Sleman Health Center, all of them were interested in making a return visit to the Cangkringan Sleman Health Center. However, eight out of 15 respondents were interviewed, 


\section{METHOD}

\subsection{Univariate Analysis}

This study examines the relationship between the quality of health services and the interest in repeat visits of patients at the Cangkringan Sleman Health Center, totaling 75 respondents. Patient characteristics are listed in Table 1.

Table 1 Characteristics of Respondents at Cangkringan Sleman Health Center

\begin{tabular}{|c|c|c|c|}
\hline \multicolumn{2}{|c|}{ Characteristics of Respondents } & Total (n) & Percentage $(\%)$ \\
\hline \multirow[t]{8}{*}{ Age } & Early Adolescence (12-16 years) & 1 & 1.3 \\
\hline & Late Adolescence ( $17-25$ years) & 9 & 12.0 \\
\hline & Early Adults (26-35 years) & 16 & 21.3 \\
\hline & Late Adults ( $36-45$ years) & 12 & 16.0 \\
\hline & Early Elderly ( $46-54$ years old) & 20 & 26.7 \\
\hline & Late Elderly (56-65 years) & 7 & 9.3 \\
\hline & Seniors $(>65$ years $)$ & 10 & 13.3 \\
\hline & Total & 75 & $100 \%$ \\
\hline \multirow[t]{3}{*}{ Gender } & Man & 27 & 36 \\
\hline & Woman & 48 & 64 \\
\hline & Total & 75 & $100 \%$ \\
\hline \multirow[t]{6}{*}{ Education } & No school & 1 & 1.3 \\
\hline & $\mathrm{SD}$ & 10 & 13.3 \\
\hline & junior high school & 24 & 32 \\
\hline & senior High School & 32 & 42.7 \\
\hline & College & 8 & 10.7 \\
\hline & Total & 75 & $100 \%$ \\
\hline \multirow[t]{8}{*}{ Work } & Farmer & 18 & 24 \\
\hline & Laborer & 4 & 5.3 \\
\hline & Private & 17 & 22.7 \\
\hline & Trader & 4 & 5.3 \\
\hline & civil servant & 4 & 5.3 \\
\hline & Housewife & 22 & 29.3 \\
\hline & Student & 6 & 8 \\
\hline & Total & 75 & $100 \%$ \\
\hline
\end{tabular}

Based on table 1, it is known that the highest percentage of patients is female, as many as 48 respondents $(64 \%)$ and 27 respondents $(36 \%)$ are male, with the highest percentage of early elderly being 20 respondents $(26.7 \%)$. the lowest is one respondent $(1.3 \%)$ with early adolescence. The highest percentage level of education is SMA as many as 32 respondents $(42.7 \%)$, while the level of education with the lowest percentage is one respondent $(1.3 \%)$ who is not in school. And the job status of housewives with the highest percentage is 22 respondents $(29.3 \%)$, while the lowest percentage of work is four respondents $(5.3 \%)$ with workers, traders, and civil servants.

Table 2 Frequency Distribution of Patient Health Service Quality at Cangkringan Sleman Public Health Center

\begin{tabular}{lcc} 
Variable & Amount & Percentage (\%) \\
\hline Very good & 54 & 72.0 \\
Well & 21 & 28.0 \\
Not good & 0 & 0 \\
Not good & 0 & 0 \\
\hline Total & $\mathbf{7 5}$ & $\mathbf{1 0 0} \%$
\end{tabular}

Based on table 2, it is known that from 75 respondents, assessing health services from Cangkringan Health Center is very good, namely as many as 54 respondents (72.0\%). While the patients who stated that the quality of health services were good were 21 respondents $(28.0 \%)$.

Table 3 Frequency Distribution of Patient Revisit Interests at Cangkringan Sleman Health Center

\begin{tabular}{lcc} 
Variable & Amount & Percentage (\%) \\
\hline Interested & 71 & 94.7
\end{tabular}

The Relationship between Health Service Quality and Patient Revisit Interest at Cangkringan Sleman Health Center, Kunik Afifah 


\begin{tabular}{lcc} 
Not interested & 4 & 5.3 \\
\hline Total & 75 & $100 \%$
\end{tabular}

Based on table 3, it is known that out of 75 respondents, as many as 71 respondents $(94.7 \%)$ were interested in getting services from the Cangkringan Health Center and four respondents $(5.3 \%)$ were not interested in getting services from the Cangkringan Sleman Health Center again.

\subsection{Bivariate Analysis}

The relationship between the quality of health services and the interest in repeat visits of patients at the Cangkringan Sleman Health Center uses the Contingency Coefficient test which is presented in table 4.

Table 4 Relationship between Health Service Quality and Patient Revisit Interest at Cangkringan Sleman Health Center

\begin{tabular}{lcccccccc} 
Quality of & \multicolumn{9}{c}{ Revisit Interest } & \multicolumn{2}{c}{ Total } & \multirow{2}{*}{$\begin{array}{l}\text { N } \\
\text { health }\end{array}$} & \multicolumn{2}{c}{ Interested } & \multicolumn{2}{c}{ Not interested } & & & $\mathrm{p}$ & $\mathrm{p}$ \\
services & $\mathrm{n}$ & $\%$ & $\mathrm{n}$ & $\%$ & $\mathrm{n}$ & $\%$ & & \\
\hline Very good & 53 & 70.7 & 1 & 1.3 & 54 & 72 & & \\
Well & 18 & 24 & 3 & 4.0 & 21 & 28 & & \\
Not good & 0 & 0 & 0 & 0 & 0 & 0 & 0.241 & 0.031 \\
Not good & 0 & 0 & 0 & 0 & 0 & 0 & & \\
\hline Total & 71 & 94.7 & 4 & 5.3 & 75 & 100 & &
\end{tabular}

Based on table 4, it is known as many as 75 respondents, there are 53 respondents $(70.7 \%)$ who stated that the quality of health services was very good and were interested in making repeat visits, while respondents who stated that the quality of health services were very good and were not interested in repeat visits were one respondent $(1,3 \%)$. And as many as 18 respondents $(24 \%)$ stated that the quality of health services was good and were interested in making repeat visits, while three respondents $(4.0 \%)$ stated that the quality of health services was good and were not interested in making repeat visits to the Cangkringan Sleman Health Center. The results of the contingency coefficient test obtained $\mathrm{p}=0.031(\alpha<0.05)$, which means that there is a significant relationship between the quality of health services and the interest in repeat visits of patients at the Cangkringan Sleman Health Center.

\section{RESULTS AND DISCUSSION}

\subsection{Patient Characteristics at Cangkringan Sleman Health Center}

Based on table 1, the percentage of respondents who stated the quality of health services at the Cangkringan Sleman Health Center were female, namely 48 respondents (64\%) compared to 27 respondents (36\%). Most of the respondents who visited the Cangkringan Sleman Health Center were early elderly with a percentage of 20 respondents $(26.7 \%)$ while the lowest age percentage was one respondent $(1.3 \%)$ with early adolescents. Most of the respondents with the highest percentage of education level were SMA as many as 32 respondents (42.7\%), and the lowest percentage of education level was one respondent $(1.3 \%)$ who did not attend school. And the work status of housewives with the highest percentage of 22 respondents $(29,3 \%)$ while the lowest percentage of work is four respondents $(5.3 \%)$ with workers, traders, and civil servants. Based on age characteristics, the age group that utilizes health services at the Cangkringan Sleman Health Center with the highest percentage is the early elderly with 20 respondents $(26.7 \%)$.

Based on gender characteristics, the majority of respondents who visited the Cangkringan Sleman Health Center were female, as many as 48 respondents (64\%). The gender factor is one of the factors that influence the utilization of health services because in terms of the level of human vulnerability that comes from gender, the level of utilization of health services is also different for each gender. Respondents who are female use health services more than male respondents, because women have more time at home as housewives compared to men who have to work outside the home as the head of the family. This is also seen because women have a greater level of concern than men who are slightly less concerned, so women pay more attention to health conditions by going to health 
services (Puskesmas) when they feel sick. Although the gender variable did not have a significant relationship with the use of dental and oral health services in hospitals, female respondents used dental and oral health services more than male respondents. Usually people with low education lack awareness and good knowledge about the benefits of health services. The education level of the respondents, most of whom have secondary education and above, greatly influences knowledge, attitude and behavior of respondents about the interest of patient visits at the Cangkringan Sleman Health Center. Based on the characteristics of the job, work is defined as an activity that is used to meet the needs of life and as a means to earn income as a reward for the activities that have been carried out. Most of the respondents' occupations were housewives with 22 respondents $(29.3 \%)$. Work affects respondents in perceiving the expectations and satisfaction of respondents for the interest in repeat visits with services provided by the Cangkringan Sleman Health Center, where a patient who works with a secondary education level, affects the insight and pattern of utilization of health services and affects knowledge,

Based on Table 2, it was found that 75 respondents, 54 respondents stated that the quality of health services was very good $(72.0 \%)$. A total of 21 respondents stated that the service quality was good $(28.0 \%)$. In this study, the assessment of the quality of health services uses a questionnaire consisting of 35 questions consisting of questions of physical evidence (tangibles), reliability (reliability), responsiveness (responsiveness), assurance (assurance), and empathy (emphaty). The format used in the questionnaire is a Likert Scale format. This is supported by the statement from Tjiptono (2001) that customer satisfaction can provide several benefits including the relationship between the company and its customers to be harmonious, providing a good basis for repeat purchases, can encourage the creation of customer loyalty, form a word of mouth recommendation that is profitable for the company, the company's reputation becomes good in the eyes of customers. The results of this study are in line with research conducted by Widyo Kunto, namely there is a significant relationship between patient perceptions of the quality of health services consisting of physical evidence (tangibles), reliability (reliability), responsiveness (responsiveness), assurance (assurance), and empathy. (emphaty) with an interest in the reuse of general inpatient services at the Leprosy Hospital Kelet Jepara. In addition, research from Trimurthy IGA also shows the same result, namely there is a relationship between patient perceptions of the quality of health services which consists of physical evidence (tangibles), reliability (reliability), responsiveness (responsiveness), assurance,

Based on the results obtained from 75 respondents, as many as 71 respondents $(94.7 \%)$ were interested in getting services from the Cangkringan Health Center and four respondents $(5.3 \%)$ were not interested in getting services from the Cangkringan Health Center, Sleman. Revisit interest is a desire that appears as a respondent to an object that shows the customer's desire to make a repeat purchase. Factors that influence the interest of patient visits are rates and location. Factors that influence interest in reuse are trust, knowledge, attitude, service quality, tariffs/costs, facilities and personnel services. This study shows that most of the patients are interested in re-utilization to the Cangkringan Sleman Health Center.

\subsection{Discussion}

Contingency coefficient correlation test results obtained $p=0.031(\alpha<0.05)$ which means that there is a significant relationship between the quality of health services and the interest in repeat visits, namely the more patients who visit, the better the service quality of Cangkringan Sleman Health Center. Cangkringan Sleman Health Center is a health service unit that is of interest to the surrounding community, but if the Cangkringan Sleman Health Center does not improve the quality of service, it will gradually reduce public interest in utilizing the services of the Cangkringan Sleman Health Center. This can be seen from table 4.4, showing that there are some people who assess the quality of service as very good, namely as many as 53 respondents $(70.7 \%)$. Meanwhile, 18 respondents stated good service quality $(24.0 \%)$.

Customer dissatisfaction should be addressed immediately because according to Armen (1996) it is stated that $70 \%$ of dissatisfied customers will make another repeat visit if they can solve the problem of dissatisfaction in accordance with the wishes of the customer and $95 \%$ of satisfied 
customers will return again for a repeat visit. On the other hand, the basis of true loyalty lies in customer satisfaction, where service quality is the main input. Very satisfied customers will be interested in making repeat visits. This is also in accordance with what was stated by (Pasuraman, 1986) in Tjiptono (2009), if the service in terms of perceived service is as expected, then the service quality is perceived to be good and satisfactory. Where according to Suryani (2008), in the process of perception consciously or unconsciously, consumers will associate with all the information they have in order to be able to give the right meaning. The information is in the form of experiences and psychological conditions of consumers such as needs, expectations and interests. And this is also in accordance with what was stated by Kotler (2009) and Hartono (2010) which states that repurchase interest is part of post-purchase behavior, after buying a product, consumers will get a feeling of satisfaction or dissatisfaction. Satisfaction and dissatisfaction with the product will affect subsequent consumer behavior. If the consumer is satisfied, then he will show a higher probability of repurchasing the product. This is in line with research from Niti (2009) and Maslina (2011),

Good service quality will provide satisfaction to customers which in the end customers will reuse and recommend these health services to people around them. So that it affects the decision to repurchase which will affect consumer speech about the services provided. Good and quality services will increase the number of visits which in turn will increase the income of the puskesmas.

In this study, there were several obstacles that were found during the research process that the researchers could not predict when the research was still being conducted, namely often respondents did not want to fill out the questionnaire themselves, so the researcher had to read the questionnaire to the respondent and there were prospective respondents who did not want to fill out the questionnaire, So the researcher must look for other potential respondents.

\section{CONCLUSION}

Based on the results of the research conducted, it was concluded that most of the respondents stated that the service was very good, as many as 54 respondents $(72.0 \%)$ of the services provided by the Cangkringan Sleman Health Center. Most of the respondents were interested in getting services from the Cangkringan Sleman Health Center, as many as 71 people (94.7\%). There is a positive and significant relationship between the quality of health services and the interest in repeat visits of patients at the Cangkringan Sleman Health Center $(r=0.241, p=0.031,<0.05)$.

Promoting public health centers as community health centers that serve promotive and preventive services, not only as curative and rehabilitative services, promoting existing programs in health centers both basic six as well as existing development programs and fostering a relationship of trust with the community so as to generate positive suggestions for the community. Puskesmas improve the quality of health services both by increasing competence and work motivation and increasing community participation development through organized community groups, for example: UKK, Youth Welfare Group.

\section{REFERENCES}

[1] L. Maulina, T. A. Madjid, and I. Chotimah, "HUBUNGAN MUTU PELAYANAN KESEHATAN DENGAN KEPUASAN PASIEN PESERTA BPJS DI UNIT RAWAT INAP PUSKESMAS CIBUNGBULANG KABUPATEN BOGOR TAHUN 2018,” PROMOTOR, vol. 2, no. 2, 2019, doi: 10.32832/pro.v2i2.1798.

[2] A. Saputra and N. Ariani, "Hubungan Mutu Pelayanan Kesehatan Dengan Kepuasan Pasien Rawat Jalan Pengguna Kartu BPJS di Rumah Sakit Daerah Idaman Kota Banjarbaru,” Borneo Nurs. J., vol. 1, no. 1, 2019.

[3] N. N. D. S. Dewi, "Hubungan Mutu Pelayanan Kesehatan dengan Kepuasan Pasien Tanggungan BPJS di Klinik Bhayangkara Polda Bali," J. Med. Karya Ilm. Kesehat., vol. 5, no. 2, 2020, doi: 10.35728/jmkik.v5i2.104.

[4] J. Oktobiannobel, N. Sahara, and E. Utari, "HUBUNGAN MUTU PELAYANAN KESEHATAN DAN KEPUASAN PESERTA BPJS DI POLIKLINIK PENYAKIT DALAM RUMAH SAKIT ABDUL MOELOEK PROVINSI LAMPUNG2015,” J. Ilmu Kedokt. dan Kesehat., vol. 6, no. 2, 2019, doi: 10.33024/jikk.v6i2.2292.

[5] I. S. E. Meruntu, R. E. Wowor, and A. A. Rumayar, "Hubungan antara Mutu Jasa Pelayanan Kesehatan 
dengan Kepuasan Pasien Rawat Jalan,” J. Public Heal. Community Med., vol. 1, no. 2, 2020.

[6] L. H. Kusumawardani and A. A. Saputri, "Gambaran Pengetahuan, Sikap dan Keterampilan Perilaku Hidup Bersih Sehat (PHBS) Pada Anak Usia Sekolah,” J. Ilm. Ilmu Keperawatan Indones., vol. 10, no. 02, 2020, doi: 10.33221/jiiki.v10i02.514.

[7] E. Eliya Astutik, "Hubungan Mutu Pelayanan Kesehatan Dengan Kepuasan Pasien Peserta BPJS Rawat Jalan Di Puskesmas," J. Kesehat. dr. Soebandi, vol. 8, no. 2, 2020, doi: 10.36858/jkds.v8i2.243.

[8] R. A. Lubis, A. D. Putri, T. Ginting, and . D., "HUBUNGAN MUTU PELAYANAN KESEHATAN DENGAN KEPUASAN PASIEN RAWAT JALAN DI PUSKESMAS SEI MENCIRIM MEDAN TAHUN 2020," J. KEPERAWATAN DAN Fisioter., vol. 3, no. 1, 2020, doi: 10.35451/jkf.v3i1.467.

[9] M. Andriane and H. Susmaneli, "Hubungan Kualitas Pelayanan kepada Pasien Terhadap Minat Kunjungan Ulang di Instalasi Rawat Jalan Rumah Sakit Umum Daerah Kecamatan Mandau Kabupaten Bengkalis Tahun 2017,” J. Kesehat. Komunitas, vol. 4, no. 3, 2019, doi: 10.25311/keskom.vol4.iss3.267.

[10] A. S. Mualifah, R. Hidana, and S. Pujiati, "GAMBARAN MUTU PELAYANAN KESEHATAN TERHADAP MINAT KUNJUNGAN ULANG PASIEN DIABETES MELLITUS DI PUSKESMAS MEKAR WANGI KOTA BOGOR TAHUN 2019," PROMOTOR, vol. 2, no. 6, 2019, doi: 10.32832/pro.v2i6.3134.

[11] H. Al Rasyid and A. T. Indah K, "Analisis Kualitas Pelayanan dan Brand Image Terhadap Minat Kunjungan Ulang Pasien Klinik Bidan Marlina,” J. Perspekt., vol. 17, no. 1, 2019, doi: 10.31294/jp.v17i1.5218. 